\title{
Restoration at the landscape scale as a means of mitigation and adaptation to climate change
}

\author{
Betsy von Holle ${ }^{1}$ (D) Stephanie Yelenik ${ }^{2} \cdot$ Elise S. Gornish ${ }^{3}$ \\ Published online: 22 July 2020 \\ (C) The Author(s) 2020
}

\begin{abstract}
Purpose of Review Although landscape-scale restoration efforts are gaining traction worldwide, their success is generally unknown. We review landscape-scale restorations to gain insight to whether focal ecological outcomes have been achieved, in the face of changing environmental conditions.

Recent Findings Only 9\% of the 477 articles that resulted from our search were studies of landscape-scale restorations. The majority (73\%) of the landscape restorations from our study have occurred since the 1990s, indicating that this type of restoration has gained in popularity in the last 30 years. Furthermore, $67 \%$ of these restoration studies occurred in a single country: China. Many scientific studies have addressed the ability of a species to shift ranges with climate change, yet few of the landscape-scale restoration studies used for our study addressed this question. Instead, $87 \%$ of the studies focused on ecosystem function, rather than community-level processes, as a result of restoration.

Summary There is a clear need for more research to be undertaken on the ecological outcomes of landscape-scale restorations to understand whether they enable species and communities to shift their ranges or adapt to climate change. Conservation practitioners could utilize our decision matrix as a tool to guide restoration of individual sites within a landscape context, as well as current and future climatic conditions, to guide ecological outcomes of interest. Optimal biodiversity maintenance requires habitat conservation in concert with restoration activities at the landscape scale, and the latter, likely increasingly so in a world of changing climate.
\end{abstract}

Keywords Landscape-scale restoration $\cdot$ Climate mitigation $\cdot$ Terrestrial $\cdot$ Adaptation to climate change $\cdot$ Restoration decision matrix

This article is part of the Topical Collection on Interface of Landscape Ecology and Conservation Biology

Betsy von Holle mvonholl@nsf.gov

Stephanie Yelenik syelenik@usgs.gov

Elise S. Gornish

egornish@email.arizona.edu

1 Division of Environmental Biology, National Science Foundation, 2415 Eisenhower Avenue, Alexandria, VA 22314, USA

2 US Geological Survey, Pacific Island Ecosystems Research Center, Reston, VA, USA

3 School of Natural Resources and the Environment, University of Arizona, Tucson, AZ, USA

\section{Introduction}

\section{Restoration as a Means of Adaptation to Climate Change}

Climate and land-use change are some of the primary drivers of species declines $[1,2]$. Conservation biology has incorporated climate change effects into reserve design, addressing the challenges of range shifts, changes in abundance, ecological forecasting models, and geographic differences in the magnitude of species response to climate change [3-5]; however, much of the current climate change adaptation literature understandably deals with habitat conservation [3-5] while restoration receives less attention [6-8]. In addition, much of the literature that addresses the use of restoration to mitigate climate change effects on species or ecosystems is often conceptual in scope, rather than an empirical report on 
implemented projects (e.g., [8-10]). Restoration must be planned in the context of (and cannot be a substitute for) habitat conservation [10,11].

There has been considerable time and energy by practitioners of landscape ecology devoted to identifying "conservation gaps"- unprotected areas harboring communities and species underrepresented in current protected networks [12-15]. Recently, this idea has been extended to restoration - identifying parts of the landscape not necessarily in ideal condition, but whose restoration would help fill gaps in current protected networks [16•]. In the era of climate change, this idea could be extended to identifying not only degraded areas that fill gaps, but even current natural areas, which could be targeted as habitat suitable for future communities as the climate changes [17].

Practical solutions to mitigate the loss of biodiversity due to climate change include protecting and managing natural areas, direct species management, monitoring existing changes, and planning for future changes, as well as policy development [4]. A portfolio approach at the landscape scale, including a range of interventions, such as maintenance of high quality conservation lands and restoration of altered areas, has been suggested as the best way to benefit biodiversity and ecosystem function [18•]. Ecological restoration, "the process of assisting the recovery of an ecosystem that has been degraded, damaged, or destroyed" [19], is an approach that provides particular utility for addressing habitat-level changes associated with a changing climate. Restoration at the landscape scale can be used to test the effects of spatial patterns on ecological processes at larger scales [20,21], as well as to redesign and proactively manage ecosystems so that they provide the services essential for all species, conserve biodiversity, and mitigate climate change $[8,22]$.

\section{Restoration at the Landscape Scale as a Means of Mitigation and Adaptation to Climate Change}

Restoration provides two key management approaches to mitigate the effects of climate change: sequestering carbon through the establishment of green biomass, and the conservation and restoration of biodiversity and ecosystem services [19]. Landscape-scale restoration approaches include regional-scale corridors to allow natural dispersal and range shifts, planting communities to provide direct or indirect protection from climate hazards, or the creation of novel ecosystems through assisted migration of species [8,23]. Restoration as a means for climate mitigation has global benefits, whereas restoration as a means of adapting to climate change has benefits at the local and regional scales [24•]. Although landscape-scale restoration approaches are likely key for arresting and mitigating negative effects of climate change, they are often not widely used due to logistic and financial feasibility issues (e.g., [25]).
Assisted migration (human transportation of individuals of a species to its projected range) is a technique that has been proposed to meet some goals of ecological restoration in a changing world, yet it is not "restoration" in the sense of reinstating a local ecosystem or habitat involving multiple species and trophic levels. While assisted migration to bring back a keystone species such as a top predator or seed disperser could be considered restoration as we define it, we do not consider any form of assisted migration or "rewilding" in our review, because the scale at which most assisted migration efforts typically focus on is at the site [26, 27].

Restoration is valuable for addressing climate change effects because it can be deployed at landscape-level scales, which is relevant to both changing environmental conditions and management parcels. Ecological reasons for considering the landscape scale in restoration include the following: (1) landscape context matters for ecosystem function; (2) overall habitat cover in any given landscape affects the ability of restored areas to support viable populations of species; (3) ecologically important processes such as dispersal and disturbance occur at the landscape scale; and (4) movement of species in response to global environmental changes occurs at the landscape scale $[28 \bullet \bullet$. Here, we define landscape-scale restoration as ecological restoration efforts that incorporate landscape-level processes, such as the flow of genes, individuals, materials, and energy across large areas that may not be possible in smaller projects [23]. Landscape-scale restoration includes large, contiguous, or fragmented areas (equal to or greater than $1 \mathrm{~km}^{2}$ ) [29].

Many international commitments have been made for global restoration goals, including the CBD Aichi Target 15, the UNFCCC REDD+ goal, the Rio + 20 land degradation neutrality goal, and, most recently, the UN Decade on Ecosystem Restoration [30, 31••]. In 2011, a global initiative called the Bonn Challenge was founded "to bring 150 million hectares of the world's deforested and degraded land into restoration by 2020 , and 350 million hectares by 2030" [32]. Although landscape-scale restoration efforts are gaining more traction worldwide, the success of these restoration actions is unknown in most cases [33••]. In order to assess biodiversity responses to landscape-scale restoration initiatives, monitoring is needed to encompass immediate to long-term ecological responses to management efforts, so that we can evaluate the underlying biological mechanisms responsible for biodiversity response to restoration [33••]. Our central focus in this review is on the ecological outcomes of landscape-scale restorations so that we can gain insight on the objectives of landscape-scale restorations and whether focal outcomes have been achieved. In this review, we focus on how restoration is used as a landscape-scale strategy in mitigating and adapting to climate change which is unlike approaches of other reviews about restoration, which are not scale-specific [24•, 34], or do not focus on climate change [23]. The focus of this paper is to 
organize and describe immediate to long-term ecological outcomes of landscape scale, terrestrial restoration in the face of changing environmental conditions.

\section{Methods}

We reviewed the published literature on the underlying rationale for landscape-scale restoration efforts and whether they reached their projected outcomes: biodiversity conservation, which may include species monitoring efforts; landscape connectivity, which may include monitoring efforts of dispersal or migration; or ecosystem function and climate resilience, which may include monitoring a single ecosystem service $[33 \bullet \bullet$. We surveyed the literature for evidence of these landscape-scale restoration efforts and their ecological outcomes. Furthermore, we provide a decision matrix for potential restoration actions, given the landscape position of the land parcel under consideration as well as current and future climatic conditions.

We searched the ISI Web of Science for articles published between 2009 and 2018, to capture the literature on this topic from the prior 10 years, which has not yet been covered in the literature [21]. Searches were conducted in March of 2019. Published articles on the topic of landscape-scale restoration as a means of adapting to or mitigating climate change were selected based on the following search terms for topics: (restor* OR reveg* OR reforest* OR refaun* OR rewild) AND (landscape scale OR large scale OR broad scale OR forest wide OR watershed) AND (ecol* OR conservation OR ecosystem service* OR ecosystem function* OR climate resilienc* OR range shift* OR refug* OR connectivity OR dispersal ) AND ("climate change" OR "environ* var*") NOT (ocean OR sea OR pelagic OR lake OR river OR limnology OR fish OR aquatic). Studies included were restricted to individual studies that involved landscape-scale terrestrial restoration for the purposes of biodiversity conservation, landscape connectivity, or ecosystem functioning. These specific terms were chosen to reflect the restoration of biodiversity at the landscape scale, in order to adapt to or mitigate climate change. We collected the following data from the text of all articles resulting from our search terms: publication year, whether the study described or quantified the outcomes of a terrestrial restoration, if the restoration was at the landscape scale (greater than $1 \mathrm{~km}^{2}$ ) [29], whether the study was an individual study, review of multiple restorations, policy paper, or model. Review papers policy papers, and models were not covered in the survey to avoid overlap, and aquatic habitats were excluded to focus the scope of the review on terrestrial systems. If the article was an individual study describing the outcomes of a landscape-scale restoration, the following data were collected: whether the study mentioned climate change adaptation or mitigation as an outcome, the objective of the study, the country where the restoration took place, habitat type for restoration, land use prior to restoration, global change factors that were the impetus for the landscape scale restoration studies (e.g., changes in water, temperature, $\mathrm{CO}_{2}$ sequestration, nonnative species invasion, human land use, fragmentation), type of restoration (active or passive), biota used (e.g., multiple, seeds, seedlings, none), whether fire was used in the restoration, start and end date of the restoration, type of practitioner conducting the restoration, years of monitoring, monitoring method, monitoring focus (e.g., vegetation cover, vegetation growth (net primary productivity [NPP]), basal area increment, water yield, species richness, species abundance, carbon sequestration), restoration outcome focus (ecosystem function, more robust populations of species of conservation concern, maintained or increased species richness), and whether the restoration was considered a success. The restoration was counted as a success if the response variable of interest was higher in the restoration plots, compared with the non-restored areas, or after restoration, compared with prior to restoration.

\section{Results}

Of the 477 articles that resulted from our search terms, $58 \%$ were individual studies, $23 \%$ were reviews, $14 \%$ were models, and $5 \%$ were policy papers. Ninety-four $(20 \%)$ of these studies described restorations, either active or passive. Of these 94 studies, 41 were conducted at the landscape scale (treatments deployed on greater than $1 \mathrm{~km}^{2}$ of area), and 28 of these studies mentioned climate change as the impetus for the restoration, or as a factor in the outcome of the restoration. Of these 28 landscape-scale restoration studies that mention climate change, 21 were appropriate to use for the study. Reasons for elimination of seven landscape-scale restoration studies included aquatic restorations or not enough methodological detail to understand the restoration treatments (e.g. not comparing restoration outcomes with a control or previous time to measure success, not stating when the restoration activities began, or not describing the restoration activities adequately). Of these 21 studies, we eliminated another 6 studies, which focused on the same dependent variable (e.g., using different methods to assess carbon sequestration) for the identical large-scale restoration. For those studies that were investigating the same dependent variables for the same restoration, we included the largest studies, in terms of the overall size of the restoration of study $\left(\mathrm{km}^{2}\right)$. Thus, while we utilized 15 independent studies, there were only a total of 11 independent landscape-scale restorations, as five of the studies were focused on the same restoration project, the Grain for Green Program in China, a program started in 1999 that focuses on replacing degraded farmland with forested landscapes [35]. Although five studies focused on this program, these papers 
differed in the focal outcome described (NPP, carbon sequestration, water yield, land surface temperatures, and vegetation cover).

Of the 15 papers we deemed appropriate for this review, one of the studies took place in Argentina, ten took place in China, two in Ethiopia, one in Wales, and one in the USA (Table 1) [36-50]. The large-scale restorations occurred in a variety of habitat types. Twelve restorations included multiple habitats (including some combination of grassland, forest, or shrubland habitats), two in forested habitats, and one restoration occurred in a peatland (Table 1). The size of the restored area varied greatly, between 1.9 million and $2.4 \mathrm{~km}^{2}$.

One of the restorations was started as early as $1949,20 \%$ of the restorations were initiated in the 1970 s, $47 \%$ of the restorations started in the $1990 \mathrm{~s}$, and $27 \%$ of the restorations were initiated in the 2000s (Fig. 1). Seven of the studies were monitored for less than 5 years, four of the studies were monitored between 9 and 14 years, and four of the studies were monitored for longer than 20 years, with the longest being monitored for 37 years. The type of practitioner who managed the restorations was primarily Federal (6 restorations, composed of 11 studies of varying focus, e.g., carbon sequestration, water yield, vegetation cover), three studies were conducted by a variety of practitioners (Federal, university, and state), and one academic institution initiated a large-scale restoration experiment. Nine studies used a form of remote sensing for monitoring, five studies used surveys where observations or samples were collected in the field, and one study involved a combination of a field study and remote sensing.

A variety of global change factors served as the impetus for the landscape-scale restoration studies (Table 1). Five of the landscape-scale restoration studies were designed to understand some aspect of changing water conditions (e.g., drought, hydrology, or altered precipitation regimes), three were designed to study carbon sequestration, three were designed to counter human land use, and four were designed to understand how restoration could counter multiple global change factors (e.g., some combination of carbon sequestration, human land use, water, and temperature affects). Thirteen of the studies focused on ecosystem function (carbon sequestration (4), NPP (4), water yield (3), land surface temperature (1), and vegetation cover (1)) as the restoration outcome, one research study looked at the increase in species richness, and one project investigated how a population of conservation concern was affected by the restoration treatment (Table 1).

The types of land uses that resulted in degradation of the landscapes included cropping, grazing, and logging and inhibition of natural disturbance regimes, and five landscapes had multiple land use types occurring across the study area. Eleven of the restorations were active, where some sort of management activity occurred (e.g., planting seeds, plants, using fire, or altering hydrological regimes), and four were passive, where the degrading activity was arrested or removed, with no follow up management action, and the land was allowed to follow natural succession trajectories [51]. Five of the large-scale restoration projects did not use biota for the restoration, four added plants, two planted seeds, one project added plants and seeds, and three of the papers did not clarify what form of materials were used for restoration (Table 1). Only one of the 15 studies used fire as a restoration tool.

Twelve of the focal landscape-scale restoration studies were considered a success for the monitoring outcome of interest. Three of these landscape-scale restoration studies were considered failures. All three of these studies monitored water yield before and after the restoration experiment. In all three cases, water yield decreased because of an increase in evapotranspiration due to increased vegetation cover. In one case [41], the restoration practitioners advised using native plants, which can reduce evapotranspiration levels compared with the non-native trees that were planted in the study.

\section{Discussion}

\section{Restoration as a Means of Adaptation to Climate Change}

Only 9\% of the 477 articles that resulted from our search terms described restorations conducted at the landscape scale. Ultimately, we were surprised by how few landscape-scale restorations have been described in the literature. This may be due to the challenges of governance and unified planning at the landscape scale [52・•]. This might also be a result of more landscape-scale restorations occurring through governmental efforts, which are typically not recorded in the peerreviewed literature, and not always monitored due to lack of resources. In a recent review of the literature of ecological management and nature conservation actions that actively allow for environmental change, the majority of studies were drawn from ecological reasoning and modeling, with only $16 \%$ based on new empirical research [53]. It is also possible that our review missed some appropriate studies if they did not explicitly use our search terms in the paper. For example, Paxton and colleagues [54] documented range shifts in both native and non-native forest birds after establishment of forest restoration corridors in Hawaii. While the restoration was originally designed in part to create avian malaria-free refugia as climates continue to warm, this paper was not a part of the 477 papers resulting from our search terms, potentially because different terms were used in the paper than our search terms, and climate change was not the major focus of the paper per se. A literature review of papers published between 2007 and 2011 of local restorations that apply a landscape assessment or landscape-scale restorations for biodiversity conservation revealed that of the 254 papers that utilized some 


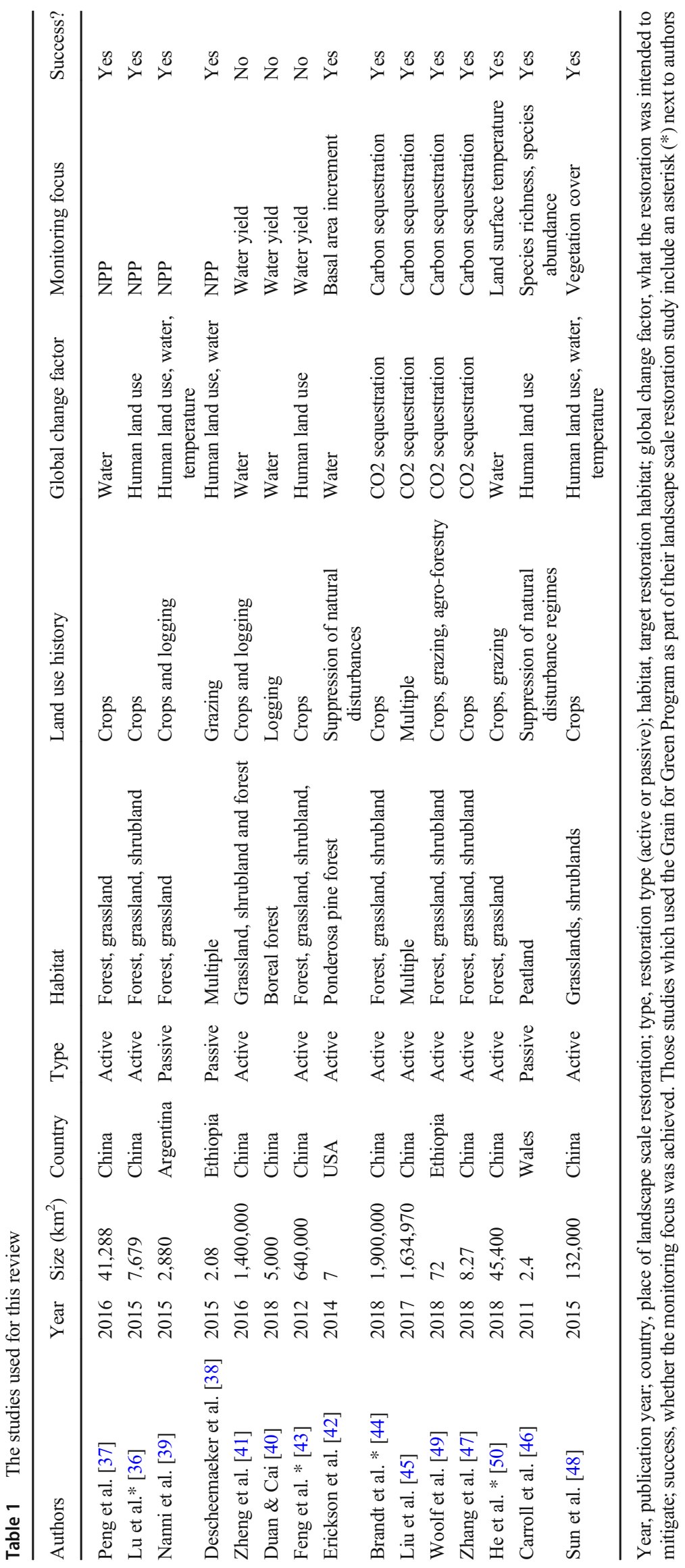




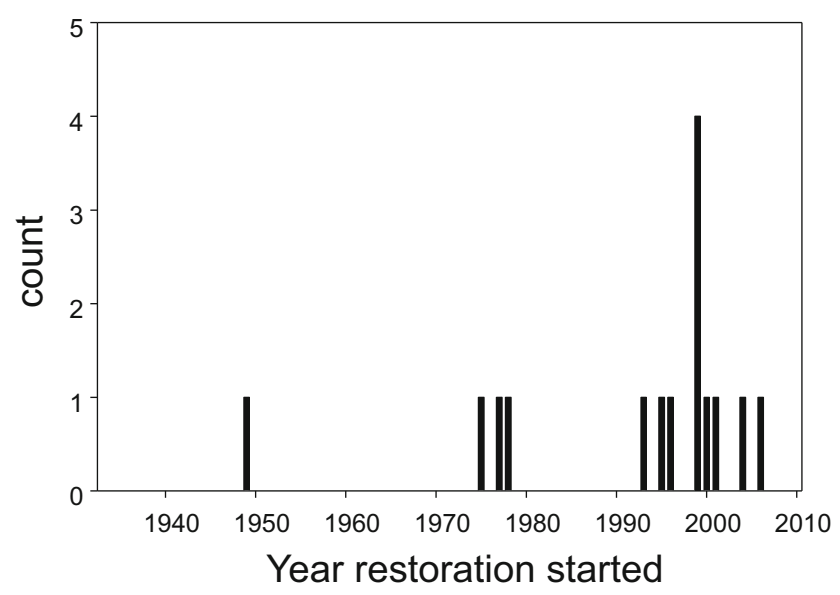

Fig. 1 Count of the year of restoration initiation of the 15 independent studies used for this review

kind of landscape application to restoration, only 11 (4\%) were landscape-scale restorations [21], similar to our result of only $9 \%$ of our studies resulting in landscape-scale restorations.

The majority (73\%) of the landscape restorations from our study have occurred since the 1990s, indicating that this type of restoration has gained in popularity in the last 30 years [21, 23], concomitant with an increase in our understanding of climate change effects $[28 \bullet \bullet]$. Furthermore, the majority of these restoration studies occurred in a single country: China (67\%). Starting in the 1970s, China prioritized landscapescale restorations across the country, which has resulted in many studies of the outcomes of these restorations, including the Grain for Green Program [43, 50]. However, other largescale restoration initiatives, such as Brazil's Atlantic Forest Restoration Pact, the National Mission for a Green India, South Africa's Working for Water program, Africa's Great Green Wall, or the Canadian and United States' Yellowstone to Yukon (Y2Y) initiative [55-59], were not captured by our literature search from the previous 10 years. This may be because most of these restorations were initiated in the last decade (with the exception of Y2Y, initiated in 1993), have not yet been quantitatively assessed for ecological outcomes of restoration success, or our search did not encompass articles describing the ecological outcomes of these landscape-scale initiatives.

Much scientific attention has been paid to the ability of a species to shift ranges with climate change [60]; thus, we were surprised that $87 \%$ of the landscape-scale restoration studies used for our study focused on ecosystem function as a result of the restoration. This may be due to the relative ease of studying outcomes of ecosystem function at the landscape scale, using methods such as remote sensing to estimate net primary production or carbon sequestration [36, 37, 44]. Furthermore, greater importance may be placed on climate mitigation, over species conservation, by restoration practitioners. An international survey of restoration actors at different policy levels revealed that rural development and climate mitigation motives were prioritized over aspects of species conservation or adaptation [61]. Clearly, more research is needed in these landscape-scale restorations to understand whether they enable species and communities to shift their ranges, or adapt to climate change.

Most measures of restoration "success" were post hoc measures, i.e., variables were decided upon by researchers well after the restoration, rather than by restoration planners at the time of project conception. Similarly, there were various approaches for deciding whether these variables (listed in Table 1) were significantly different due to restoration, including a range of samples sizes and statistical tests. For example, Liu et al. [45] used national forest inventory units, which were resampled seven times, as a unit of replication for estimating whether forest biomass carbon increased over time since reforestation. On the other hand, Erickson and Waring [42] analyzed differences in Pinus ponderosa growth between replicated restoration treatments: areas thinned and burned versus areas that were not treated. While we agree that it is best to decide on metrics of restoration success at project inception, this topic has been explored in depth elsewhere [62-65], thus we do not expand on those ideas here.

\section{How Landscape-Scale Restoration can be Used to Stem the Loss of Biodiversity due to Climate Change}

Landscape-scale restoration in response to climate change is largely expected to enhance biodiversity both within and external to the restoration area [9], as increasing landscape connectivity will increase the ability of species to respond to climate change $[66,67]$. Landscape connectivity (the development of regional-scale corridors) for mitigating climateassociated biodiversity effects, including facilitating range shifts of climatically sensitive species and enhancing opportunities for species to adapt to changing environmental conditions, may be uniquely affected by ecological landscape restoration because of the extent of areas targeted for management [66]. Despite the many ways in which larger scale restoration efforts might boost biodiversity through the creation and maintenance of corridors, none of the studies included in this review monitored range shifts or habitat connectivity. This is likely due, in part, to the fact that connectivity and range shifts are difficult to monitor over large areas, although new technologies are providing alternatives for rapid, large scale restoration monitoring (e.g., [68]). In this section, we review the ways in which landscape-scale restoration efforts are particularly well-suited to counter the loss of biodiversity due to climate change.

Range shifts are one of the most common ways for native species to respond to changes in environmental conditions [67]. Range shifts enable species to track their ideal climate 
and maintain growth rates that ensure population survival [69]. Range shifts, however, can only occur in the presence of large, contiguous natural areas or corridors for migration and microrefugia that support dispersal [70, 71]. Landscapescale restoration can create, protect, and link corridors in ways that smaller-scale restorations cannot, thereby facilitating range shifts, adaptive capacity, and conserving biodiversity $[16 \cdot, 72]$. For example, it is expected that most plant species will shift their range by $>1 \mathrm{~km}$ per year to accommodate changes in the climate [73]. Only restoration approaches that encompass large amounts of land will be able to provide the habitat needed for these shifts.

Corridors created by landscape-scale restoration can facilitate the maintenance of biodiversity in the face of climate change by providing a species with an opportunity to shift its range in response to changing environmental conditions. Species that are unable to shift their ranges might not be able to adapt quickly enough to climate change and therefore could go extinct [72]. Additionally, corridors can also increase biodiversity in other ways, such as attracting wildlife [74] and enhancing the ability of species to adapt to climate change through the reduction of fragmented habitats $[75,76]$. Corridors have also been found to increase nonnative species diversity [77-79], which may influence the ability of native species to shift their ranges [80].

In addition to enhancing biodiversity across habitats, landscape-scale restoration has particular utility for cultivating resilience (the resistance of regime shifts) to enhanced climate change effects. Landscape-scale restoration implies larger areas of habitat that are managed; therefore, large numbers of species are more likely to be added (through active restoration) or conserved (through passive restoration). More biodiverse areas are more resilient to climate change effects [81] because larger numbers of species that inhabit an area increase the likelihood that species will (1) have relevant traits to maintain ecosystem services even with local extinctions [82] and (2) be able to adapt to changing climatic conditions [83]. Rice and Emery [84] urge for the consideration of evolutionary development in conservation and restoration efforts, for a means by which species can escape extinction, in the face of rapidly changing selective pressures resulting from global change.

\section{How Landscape-Scale Restoration can be Used to Improve Ecosystem Function or Services Affected by Climate Change}

The majority of the restoration projects that we surveyed monitored some aspect of ecosystem function. Many of the studies measured changes in ecosystem variables as a post hoc question. This is not that surprising, given the fact that restoration projects take long periods of time to establish, for plant communities to stabilize (if they ever do), and for ecosystem properties to be altered by treatments [85॰]. By that time, often decades later, priorities and goals may have changed. For example, most of the Grain for Green plantings were focused on lessening erosion in degraded agricultural areas [86], while the studies highlighted here tested various ecosystem variables besides erosion (Table 1). For example, Peng et al. [37] quantified carbon sequestration, citing potential offsets relating to carbon emission targets put into place long after the original restoration efforts were organized.

In a survey of four U.S. Federal agencies that manage National Wilderness Areas [87], the most common management interventions were vegetation treatments, wildfire, and wildlife restoration in order to restore "ecosystem function," "protect habitat from invasive species," or to "restore habitat to historical or natural conditions." However, very few of the studies we included in this review were from the USA, indicating that most U.S. large-scale restoration projects are either not monitored [88], or these efforts are not published in outlets that appear on the Web of Science, such as grey literature and technical reports that may not surface with these search engines. This is often due to a lack of funding within management agencies for monitoring and a disjunct between management practitioners (those on the ground doing the restoration) and agency or academic research with funding and priorities that favor monitoring-type projects. Remote sensing may be one way to overcome this barrier, especially in terms of ecosystem variables such as total green cover, carbon storage, ground surface temperature, or modeled vegetation evapotranspiration [89]. In fact, many of the studies that quantified ecosystem variables in our study used available remote sensing imagery (e.g. MODIS).

As noted above, the interrelated NPP, biomass, and carbon sequestration variables were considered enhanced by the restoration activities (Table 1). It is possible that ecosystem function variables (e.g., improved water quality, increased nutrient retention, increased pollination, increased pest control, increased regional climate regulation) may be more attainable than traditional restoration goals, i.e., to restore the baseline community[8]. Indeed, ecosystem function, especially biomass or NPP, can return even with completely novel species assemblages (e.g., [90]). In this case, restoration practitioners could evaluate if these scenarios match project goals and whether novel assemblages are appropriate given project stakeholders. Changes in species composition from reference communities may be due to a reliance on passive restoration, the use of non-native plants as placeholders before native species are added, or the use of non-native species to fill in missing niche space due to depauperate flora [91-93]. For example, in Hawaii, non-native non-invasive species, often of cultural and/or agricultural importance, were used in lowland forest areas to maximize plant traits in a way that created resistance to invasion by more weedy species [94]. Similarly, in China's Grain for Green Program, both 
"ecological" (native to the region) and "economic" (species that could be used for agricultural or non-timber forest products) tree species were encouraged [86]. Our review indicates that such novel assemblages can still increase ecosystem services for certain variables, but may not achieve or may hinder biodiversity goals.

It can also be the case, however, that some ecosystem services decline in value. Three of the studies highlighted in this review from China showed that ecosystem variables reflecting water yield decreased since restoration efforts (Table 1, [40, 41, 43]). Water yield at the local scale may not benefit from landscape-scale restoration; however, increased evapotranspiration from restoration at these local scales will favor the cross-continental transport of moisture vapor and thus, increased precipitation in locations distant from the ocean-based hydrological cycle [95]. Additionally, restoration efforts that increase NPP and carbon sequestration can mitigate climate change [96]. In our study, water yield research captured various ecotypes, including boreal forest [40], humid and semi-humid provinces in southern China including grassland, shrubland and forest vegetation [41], and semi-arid grasslands in the Loess plateau [43]. Unsurprisingly, adding large quantities of trees, often in monoculture, to what would naturally be sparsely vegetated or grassland areas lowered water yield and stream flows relative to natural vegetation types. Indeed, the Grain for Green Program has been criticized for using resource-use inefficient species such as Populus that were not native to the immediate area or, at the very least, not native in such large numbers [86], leading to an overall loss of native, diverse forest and native vegetation more generally [97]. Such losses of water yield are particularly important in arid regions or more mesic habitats where droughts are projected to increase [41, 98]. Indeed, increasing water yield by removing rather than planting trees from fynbos shrubland is the focus of the Working for Water restoration program in South Africa [99], showing how the term restoration can be somewhat subjective.

This dichotomy-that carbon sequestration may come at the expense of other ecosystem properties such as water yield or community composition - warrants further attention, especially given recent, public calls for largescale afforestation in the face of climate change [100]. In fact, biomes such as grasslands and savannahs can hold as much belowground carbon as plantation forests, and certainly contain greater biodiversity [101]. Tree plantations can also lead to a loss of soil nutrients and overall decrease in ecosystem carbon, especially if poorly managed and harvested frequently [102]. Thus, we stress that restoration goals be clearly stated in landscape-scale projects and revisited over time with the realization that, similar to adaptive management, community assembly endpoints and ecosystem-based goals may need to be reevaluated $[23,31 \bullet \cdot]$.

\section{How Landscape-Scale Restoration can Mitigate the Loss of Biodiversity and Ecosystem Services Under Climate Change}

Our results, in part, highlighted a lack of planning for climate change in restoration projects. We thus created a decision matrix (Table 2) to guide restoration actions in the face of global climate change and meet a variety of conservation goals, including species conservation, connectivity, range shifts, and ecosystem function and resilience. Our decision matrix is based on the current climate and future climate, as well as the current "state" of the landscape in terms of disturbance level and whether remnant tracts of land are nearby. Land-use intensity influences the rate of species recovery in a restoration [103] as well as forest restoration success [10]. Some disturbances have low effects on species recovery (e.g., selective logging, hunting, or intermittent grazing), whereas high intensity land uses, such as cropping or extended grazing, can render a site unsuitable, because the availability of propagules for succession are lost from the seed bank or existing vegetation [103]. The landscape context for which a site is situated is important to recovery [10], as remnant sites with intact native vegetation can serve as propagule sources [93] to the site under consideration. Furthermore, as the climate changes, species must keep pace with the climate $[104,105]$ in order to maintain physiological functioning $[8,106]$, and this is more feasible in large protected areas where landscapes are less fragmented [107].

Our decision matrix (Table 2) was designed to evaluate sites using the current and future climate, as well as where the habitat is situated in the landscape as a framework for conservation and restoration prioritization. The landscape state is a measure of human disturbance and location and is considered "intact" if it is a site that does not present signs of human disturbance and may or may not be adjacent to other conservation areas. "Disturbed" states include sites that present signs of human disturbance and include those that adjoin intact sites or not. For example, if a piece of land occurs in an area where the climate is suitable for the focal species (which may or may not be found there currently) but will become unsuitable for those species in the future, the current landscape state determines the management outcome. In this case, if the site is intact (has not experienced human modification), that habitat could be conserved (D), to allow for colonization of species as communities shift their ranges, supporting overall 
Table 2 Habitat restoration decision matrix focused on conserving target species (or set of species with similar requirements), with simple binary suitable/unsuitable states for climate state and one of three states of the habitat in the landscape. Text in cells shows conservation or restoration actions. Bold text indicates the restoration goal

\begin{tabular}{|c|c|c|c|c|}
\hline \multirow[b]{2}{*}{$\begin{array}{l}\text { Current } \\
\text { climate }\end{array}$} & \multirow[b]{2}{*}{$\begin{array}{l}\text { Future } \\
\text { climate }\end{array}$} & \multicolumn{3}{|l|}{ Current state in the landscape } \\
\hline & & Intact (remnant/uncleared) & $\begin{array}{l}\text { Disturbed (cleared/modified) and } \\
\text { adjoining intact habitat }\end{array}$ & $\begin{array}{l}\text { Disturbed (cleared/modified) and } \\
\text { not adjoining remnant intact habitat }\end{array}$ \\
\hline Suitable & Suitable & $\begin{array}{l}\text { A. Conserve vegetation for focal } \\
\text { species (refugium) } \\
\text { Refugia - focal species } \\
\text { conservation \& connectivity }\end{array}$ & $\begin{array}{l}\text { B. Restore vegetation to expand area } \\
\text { of refugium } \\
\text { Refugia - focal species } \\
\text { conservation \& connectivity }\end{array}$ & $\begin{array}{l}\text { C. Consider potential restoration, } \\
\text { subject to context, linkage, dispersal } \\
\text { Focal species conservation } \& \\
\text { connectivity }\end{array}$ \\
\hline Suitable & Unsuitable & $\begin{array}{l}\text { D. Conserve vegetation for other, } \\
\text { non-focal, species to colonize } \\
\text { Ecosystem function \& climate } \\
\text { resilience }\end{array}$ & E. No action & F. No action \\
\hline Unsuitable & Suitable & $\begin{array}{l}\text { G. Conserve vegetation (potential } \\
\text { future habitat extent) } \\
\text { Facilitate focal species range shifts }\end{array}$ & $\begin{array}{l}\text { H. Restore vegetation to expand } \\
\text { potential future habitat extent. } \\
\text { Facilitate focal species range shifts }\end{array}$ & $\begin{array}{l}\text { I. Consider potential restoration, } \\
\text { subject to context, linkage, dispersal } \\
\text { Facilitate focal species range shifts }\end{array}$ \\
\hline
\end{tabular}

ecosystem function and climate resilience [17]. If this is a disturbed site, which has experienced human land use, priority for this habitat is low and no action would be warranted, whether it is adjacent to conservation lands or not (E, F). Human-disturbed habitats host higher levels of nonnative species, with the legacy of disturbance lasting over a century, in some cases [108]. It is possible that novel competitors, such as nonnative species, can have a greater adverse effect than shifting climate on species of concern [80], making species interactions important to consider when forecasting community response and restoration outcomes to changing climate.

Alternatively, if a piece of land is currently in unsuitable climate for focal species or communities of concern that are not currently found there, but the climate of this area is projected to become suitable for these communities in the future, the management actions also depend on the current landscape state (Table 2). For those areas that do not present signs of human land use and are considered intact, these could be future habitat for range-shifting species, and so may warrant being conserved $(\mathrm{G})$. Those areas that are disturbed and that adjoin remnant intact habitat could also be restored to allow for future habitat expansion and focal species range shifts $(\mathrm{H})$. Those degraded lands that do not adjoin intact habitats can be considered potential restoration sites in order to facilitate focal species range shifts (I), however would be lower priority than those sites adjacent to intact habitat $(\mathrm{H})$. Generally, restoration of disturbed sites that do not adjoin remnant intact habitat but are projected to have suitable future climate for focal communities (C, I) warrant consideration for restoration, given the context, spatial location, and dispersal capabilities of the focal species and communities.

\section{Conclusions}

\section{Multiple Benefits of Restoration at the Landscape Scale}

Optimal biodiversity maintenance at the landscape scale requires habitat conservation in concert with restoration activities, and the latter increasingly so in a world of changing climate. Consideration of multiple goals and benefits of restoration simultaneously, rather than in isolation from each other, depends on how on-the-ground efforts are conceived and applied [31••, 93, 109]. Restoration styles that achieve conservation and biodiversity goals can often meet many of these other targets, including mitigation through carbon sequestration [24•], given that functional diversity increases ecosystem function [110], and that all of the studies in our review that monitored ecosystem function had increases over time, with the exception of water yield. Landscapescale restoration of forests has social, economic, and environmental benefits that enhance lives of local people, mitigate effects of climate change, increase food security, and safeguard soil and water resources [52•*]. Starting at the planning stage, four general principles warrant consideration for ecological restoration at the landscape scale: increasing ecological integrity, increasing sustainability for the long-term, consideration of the past and the future, and engaging and benefiting society $[31 \cdot \bullet]$. After the restoration has been implemented, it is critically important to monitor the restoration for as long as possible [111], to assess restoration success and quantify the effects on biodiversity and ecosystem function. 


\section{Approaches}

A combination of passively managed conservation areas and actively managed restorations across the landscape may best facilitate adaptation to climate change [112], particularly if active and passive restorations have difference in recovery rates or recovery endpoints [85.]. The choice of active or passive management for any given tract of land depends on the characteristics of the landscape around the focal area, management goals and resources, degree of degradation, ecosystem resilience, and the current and future climate [31・•] (Table 2). In sites with low to intermediate levels of degradation, where soils have not been disturbed and where there are sufficient mature trees or a soil seed bank to allow for regeneration, passive management may be the best option [93, 113]. The typical scenario for wilderness area managers, who are confronted by ecological degradation, is to first determine if action is warranted, and if so, then determine the minimum tool necessary to implement the action while preserving wilderness character [87]. Passive management in natural areas may allow the environment to adapt to change unaided, which could improve adaptation to climate change and protect biodiversity [112] with an inexpensive and often logistically feasible strategy. Active management resources could be prioritized for those altered landscapes adjacent to conservation lands, which would sustain target species under future climatic conditions (Table 2, B and H) [114]. A combination of active or passive restoration followed by enrichment planting of rare and late-successional species, after the mature vegetation has established, may be the most cost-effective way of restoring rare species which are more difficult to restore [115].

Broadly, the goal of restoration in the coming decades will be to restore landscapes to allow native species to adapt to environmental conditions, while ensuring ecosystem services are maintained or restored [8]. A landscape approach to species conservation has the benefit of allowing species to shift geographically, in order to meet their physiological requirements as climate changes [8]. Landscape-scale restoration could emphasize species and genetic diversity, in order to improve ecosystem stability, productivity, resilience and recovery from climatic extremes $[31 \bullet \bullet, 116]$. The inherent complexity of landscapes and ecological challenges suggest that there may be no single way to set restoration targets [25]. Conservation practitioners can utilize our framework (Table 2) as a decision tool to guide restoration of individual sites, within the framework of the landscape context of the site under consideration, as well as current and future climatic conditions. On-theground solutions for ecological outcomes of interest are best found through discussions with scientists, managers, landscape planners, and the public [117]. Resource managers can use our decision matrix as a tool to guide a general framework for effective local solutions, within a landscape context.

Acknowledgments We gratefully acknowledge Dr. Carla Catterall for inspiring the decision matrix and for extensive discussions of the manuscript outline. Additionally, this manuscript benefitted from a discussion with Dr. Robin Chazdon. Any use of trade, firm, or product names is for descriptive purposes only and does not imply endorsement by the US Government. This manuscript is based on work done by BVH while serving at the US National Science Foundation. The views expressed in this paper do not necessarily reflect those of the National Science Foundation but do reflect the views of the U.S. Geological Survey.

Authors' Contributions BVH conceived the research topic, and BVH, $\mathrm{SY}$, and EG gathered the data and co-wrote the paper.

\section{Compliance with Ethical Standards}

Conflict of Interest Betsy von Holle, Stephanie Yelenik, and Elise Gornish declare that they have no conflict of interest.

Human and Animal Rights and Informed Consent This article does not contain any studies with human or animal subjects performed by any of the authors.

Open Access This article is licensed under a Creative Commons Attribution 4.0 International License, which permits use, sharing, adaptation, distribution and reproduction in any medium or format, as long as you give appropriate credit to the original author(s) and the source, provide a link to the Creative Commons licence, and indicate if changes were made. The images or other third party material in this article are included in the article's Creative Commons licence, unless indicated otherwise in a credit line to the material. If material is not included in the article's Creative Commons licence and your intended use is not permitted by statutory regulation or exceeds the permitted use, you will need to obtain permission directly from the copyright holder. To view a copy of this licence, visit http://creativecommons.org/licenses/by/4.0/.

\section{References}

Papers of particular interest, published recently, have been highlighted as:

- Of importance

•. Of major importance

1. Foley JA, DeFries R, Asner GP, Barford C, Bonan G, Carpenter $\mathrm{SR}$, et al. Global consequences of land use. Science. 2005;309(5734):570-4.

2. Wiens JJ. Climate-related local extinctions are already widespread among plant and animal species. PLoS Biol. 2016;14(12):18.

3. Hannah L, Midgley GF, Millar D. Climate change-integrated conservation strategies. Glob Ecol Biogeogr. 2002;11(6):485-95.

4. Mawdsley JR, O'Malley R, Ojima DS. A review of climate change adaptation strategies for wildlife management and biodiversity conservation. Conserv Biol. 2009;23(5):1080-9.

5. Root TL, Schneider SH. Conservation and climate change: The challenges ahead. Conserv Biol. 2006;20(3):706-8. 
6. Crowe KA, Parker WH. Using portfolio theory to guide reforestation and restoration under climate change scenarios. Clim Change. 2008;89(3-4):355-70.

7. Erwin KL. Wetlands and global climate change: the role of wetland restoration in a changing world. Wetl Ecol Manag. 2009;17(1):71-84.

8. Harris JA, Hobbs RJ, Higgs E, Aronson J. Ecological restoration and global climate change. Restor Ecol. 2006;14(2):170-6.

9. Heller NE, Zavaleta ES. Biodiversity management in the face of climate change: A review of 22 years of recommendations. Biol Conserv. 2009;142(1):14-32.

10. Crouzeilles R, Curran M, Ferreira MS, Lindenmayer DB, Grelle CEV, Benayas JMR. A global metaanalysis on the ecological drivers of forest restoration success. Nat Commun. 2016;7:8.

11. Young TP. Restoration ecology and conservation biology. Biol Conserv. 2000;92(1):73-83.

12. Bosso L, Rebelo H, Garonna AP, Russo D. Modelling geographic distribution and detecting conservation gaps in Italy for the threatened beetle Rosalia alpina. J Nat Conserv. 2013;21(2):72-80.

13. Fajardo J, Lessmann J, Bonaccorso E, Devenish C, Munoz J. combined use of systematic conservation planning, species distribution modelling, and connectivity analysis reveals severe conservation gaps in a Megadiverse Country (Peru). Plos One. 2014;9(12):23.

14. Huang JH, Liu CR, Zhang JL, Lu XH, Ma KP. Diversity hotspots and conservation gaps for the Chinese endemic seed flora. Biol Conserv. 2016;198:104-12.

15. Oliveira U, Soares BS, Paglia AP, Brescovit AD, de Carvalho CJB, Silva DP, et al. Biodiversity conservation gaps in the Brazilian protected areas. Sci Rep. 2017;7:9.

16. Damschen EI, Brudvig LA, Burt MA, Fletcer RJ, Haddad NM, Levey DJ, et al. Ongoing accumulation of plant diversity through habitat connectivity in an 18-year experiment. Science. 2019;365(6460):1478-80 Using a large, replicated restoration experiment, this article demonstrates that habitat patches connected by corridors retain more native plant species than do isolated patches.

17. Camp RJ, Berkowitz SP, Brinck KW, Jacobi JD, Loh R, Price J, et al. Potential Impacts of Projected Climate Change on VegetationManagement Strategies in Hawai'i Volcanoes National Park. Reston, Virginia: U.S. Geological Survey; 2018. Report No.: Scientific Investigations Report 2018-5012.

18. Hobbs RJ, Higgs ES, Hall CM. Expanding the Portfolio: Conserving nature's masterpieces in a changing world. Bioscience. 2017;67(6):568-75 To manage landscapes effectively, this article advocates for a portfolio approach to allow for a suite of goals ranging from the maintenance of existing high-value conservation assets to alternative management approaches for the altered parts of the landscape.

19. Society for Ecological Restoration. What is Ecological Restoration? Washington, D.C: Soceity for Ecological Restoration; 2019.

20. Bell SS, Fonseca MS, Motten LB. Linking restoration and landscape ecology. Restor Ecol. 1997;5(4):318-23.

21. Leite MD, Tambosi LR, Romitelli I, Metzger JP. Landscape ecology perspective in restoration projects for biodiversity conservation: a review. Nat Conserv. 2013;11(2):108-18.

22. Seabrook L, McAlpine CA, Bowen ME. Restore, repair or reinvent: Options for sustainable landscapes in a changing climate. Landscape and Urban Plan. 2011;100(4):407-10.

23. Holl KD, Crone EE, Schultz CB. Landscape restoration: Moving from generalities to methodologies. Bioscience. 2003;53(5):491502 .

24. Locatelli B, Catterall CP, Imbach P, Kumar C, Lasco R, MarinSpiotta E, et al. Tropical reforestation and climate change: beyond carbon. Restor Ecol. 2015;23(4):337-43 The premise of this article is that reforestation should be managed with both adaptation and mitigation objectives in mind, to maximize synergies between these roles, and to ensure that the direct and indirect impacts of climate change on reforestation are anticipated and minimized.

25. Lindenmayer DB, Manning AD, Smith PL, Possingham HP, Fischer J, Oliver I, et al. The focal-species approach and landscape restoration: a critique. Conserv Biol. 2002;16(2):338-45.

26. McLachlan JS, Hellmann JJ, Schwartz MW. A frmework for debate of assisted migration in an era of climate change. Conserv Biol. 2007;21(2):297-302.

27. Park A, Talbot C. Information underload: Ecological complexity, incomplete knowledge, and data deficits create challenges for the assisted migration of forest trees. Bioscience. 2018;68(4):251-63.

28.• Perring MP. In: Allison SK, Murphy SD, editors. LandscapeScale Restoration Ecology. Abingdon: Routledge; 2017. p. 3348. This book chapter outlines the fundamental ecological basis for restoration to occur at the landscape scale, as well as the challenges and opportunities of working at this scale, especially in light of global environmental change.

29. Menz MHM, Dixon KW, Hobbs RJ. Hurdles and opportunities for landscape-scale restoration. Science. 2013;339(6119):526-7.

30. Hwang BS, Eisele F. New UN Decade on Ecosystem Restoration offers unparalleled opportunity for job creation, food security and addressing climate change New York, NY: Food and Agriculture Organization of the United Nations; 2019. Available from: http:// www.fao.org/news/story/en/item/1 182090/icode/\#targetText= The $\% 20$ United $\% 20$ Nations $\% 20$ General $\% 20$ Assembly,UN\% 20Decade $\% 20$ on $\% 20$ Ecosystem $\% 20$ Restoration\&targetText= Restoration $\% 20$ of $\% 20350 \% 20$ million $\% 20$ hectares,gases $\%$ 20out\%20of\%20the\%20atmosphere.

31.• Suding K, Higgs E, Palmer M, Callicott JB, Anderson CB, Baker $\mathrm{M}$, et al. Committing to ecological restoration. Science. 2015;348(6235):638-40 In order to attain sustainable and resilient ecosystems, this paper outlines four comprehensive principles to be considered when planning for restoration.

32. DC I. Bonn challenge: restore our future Washington DC: IUCN; 2020 [Available from: https://www.bonnchallenge.org/content/ challenge].

33.• Watson DM, VAJ D, Banks SC, Driscoll DA, van der Ree R, Doerr ED, et al. Monitoring ecological consequences of efforts to restore landscape-scale connectivity. Biol Conserv. 2017;206: 201-9 This article points out that the success of restoration initiatives to improve habitat connectivity is largely unknown, and suggests new monitoring approaches which distinguish between the roles of restoration for connectivity from those of structural improvement, in order to provide consistant and comparable measures of functional connectivity.

34. Jonas JL, Grant-Hoffman MN, Paschke MW. Restoration of North American salt deserts: A look at the past and suggestions for the future. Ecol Restor. 2018;36(3):177-94.

35. Li G, Sun SB, Han JC, Yan JW, Liu WB, Wei Y, et al. Impacts of Chinese Grain for Green program and climate change on vegetation in the Loess Plateau during 1982-2015 (vol 660, pg 177, 2019). Sci Total Environ. 2019;665:1190-1.

36. Lu N, Akujarvi A, Wu X, Liski J, Wen ZM, Holmberg M, et al. Changes in soil carbon stock predicted by a process-based soil carbon model (Yasso07) in the Yanhe watershed of the Loess Plateau. Landsc Ecol. 2015;30(3):399-413.

37. Peng DL, Wu CY, Zhang B, Huete A, Zhang XY, Sun R, et al. The influences of drought and land cover conversion on interannual vriation of NPP in the Three-North Shelterbelt Program zone of China based on MODIS Data. Plos One. 2016;11(6):22.

38. Descheemaeker K, Mapedza E, Amede T, Ayalneh W. Effects of integrated watershed management on livestock water productivity 
in water scarce areas in Ethiopia. Phys Chem Earth. 2010;35(1314):723-9.

39. Nanni AS, Gasparri NI, Grau HR. Redistribution of forest biomass in an heterogeneous environment of subtropical Andes undergoing agriculture adjustment. Appl Geogr. 2015;62:107-14.

40. Duan LL, Cai TJ. Quantifying impacts of forest recovery on water yield in two large watersheds in the cold region of northeast China. Forests. 2018;9(7):18.

41. Zheng HR, Wang YQ, Chen Y, Zhao TY. Effects of large-scale afforestation project on the ecosystem water balance in humid areas: An example for southern China. Ecol Eng. 2016;89:103-8.

42. Erickson CC, Waring KM. Old Pinus ponderosa growth responses to restoration treatments, climate and drought in a southwestern US landscape. Appl Veg Sci. 2014;17(1):97-108.

43. Feng XM, Sun G, Fu BJ, Su CH, Liu Y, Lamparski H. Regional effects of vegetation restoration on water yield across the Loess Plateau, China. Hydrol Earth Syst Sci. 2012;16(8):2617-28.

44. Brandt M, Yue YM, Wigneron JP, Tong XW, Tian F, Jepsen MR, et al. Satellite observed major greening and biomass increase in south China karst during recent decade. Earth Future. 2018;6(7): 1017-28.

45. Liu WW, Lu F, Luo YJ, Bo WJ, Kong LQ, Zhang L, et al. Human influence on the temporal dynamics and spatial distribution of forest biomass carbon in China. Ecol Evol. 2017;7(16):6220-30.

46. Carroll MJ, Dennis P, Pearce-Higgins JW, Thomas CD. Maintaining northern peatland ecosystems in a changing climate: effects of soil moisture, drainage and drain blocking on craneflies. Glob Change Biol. 2011;17(9):2991-3001.

47. Zhang L, Zhao W, Zhang R, Cao H, Tan WF. Profile distribution of soil organic and inorganic carbon following revegetation on the Loess Plateau, China. Environ Sci Pollut Res. 2018;25(30): 30301-14.

48. Sun WY, Song XY, Mu XM, Gao P, Wang F, Zhao GJ. Spatiotemporal vegetation cover variations associated with climate change and ecological restoration in the Loess Plateau. Agric For Meteorol. 2015;209:87-99.

49. Woolf D, Solomon D, Lehmann J. Land restoration in food security programmes: synergies with climate change mitigation. Clim Policy. 2018;18(10):1260-70.

50. He GH, Zhao Y, Wang JH, Wang QM, Zhu YN. Impact of largescale vegetation restoration project on summer land surface temperature on the Loess Plateau, China. J Arid Land. 2018;10(6): 892-904.

51. DellaSala DA, Martin A, Spivak R, Schulke T, Bird B, Criley M, et al. A citizens' call for ecological forest restoration: Forest restoration principles and criteria. Ecol Restor. 2003;21(1):14-20.

$52 . \bullet$ Chazdon RL, Uriarte M. Natural regeneration in the context of large-scale forest and landscape restoration in the tropics. Biotropica. 2016;48(6):709-15 This article provides an overview of the ecological, economic, and social dimensions of forest and landscape restoration in the tropics, as well as how passive and assisted natural regeneration can contribute to achieving multiple social and ecological benefits.

53. Prober SM, Doerr VAJ, Broadhurst LM, Williams KJ, Dickson F. Shifting the conservation paradigm: a synthesis of options for renovating nature under climate change, Ecological Monographs. 2019;89:1

54. Paxton EH, Yelenik SG, Borneman TE, Rose ET, Camp RJ, Kendall SJ. Rapid colonization of a Hawaiian restoration forest by a diverse avian community. Restor Ecol. 2018;26(1):165-73.

55. Asen A. The Great Green Wall: UN Convention to Combat Desertification; 2007.

56. Hobbs RJ. The Working for Water programme in South Africa: the science behind the success. Divers Distrib. 2004;10(5-6):5013.
57. Y2Y. Yellowstone to Yukon Conservation Initiative (Y2Y) Canmore, Canada: Yellowstone to Yukon Conservation Initiative. 2019. Available from: https://y2y.net/publications/ introducing-y2y-2017.pdf.

58. Marais C, van Wilgen BW, Stevens D. The clearing of invasive alien plants in South Africa: a preliminary assessment of costs and progress. S Afr J Sci. 2004;100(1):97-103.

59. Pinto SR, Melo F, Tabarelli M, Padovesi A, Mesquita CA, Scaramuzza CAD, et al. Governing and delivering a biome-wide restoration iInitiative: The case of Atlantic Forest Restoration Pact in Brazil. Forests. 2014;5(9):2212-29.

60. Fordham DA, Akcakaya HR, Araujo MB, Keith DA, Brook BW. Tools for integrating range change, extinction risk and climate change information into conservation management. Ecography. 2013;36(9):956-64.

61. Reinecke S, Blum M. Discourses across scales on forest landscape restoration. Sustainability. 2018;10(3):19.

62. Zedler JB. Success: an unclear, subjective descriptor of restoration outcomes. Ecol Restor. 2007;25(3):162-8.

63. Prach K, Durigan G, Fennessy S, Overbeck GE, Torezan JM, Murphy SD. A primer on choosing goals and indicators to evaluate ecological restoration success. Restor Ecol. 2019;27(5):91723.

64. Ruiz-Jaen MC, Aide TM. Restoration success: How is it being measured? Restor Ecol. 2005;13(3):569-77.

65. Wortley L, Hero J-M, Howes M. Evaluating ecological restoration success: A review of the literature. Restor Ecol. 2013;21(5):53743.

66. Beier P. Conceptualizing and designing corridors for climate change. Ecol Restor. 2012;30(4):312-9.

67. Walther GR. Community and ecosystem responses to recent climate change. Philos T R Soc B-Biological Sciences. 2010;365(1549):2019-24.

68. Shuman CS, Ambrose RF. A comparison of remote sensing and ground-based methods for monitoring wetland restoration success. Restor Ecol. 2003;11(3):325-33.

69. Aitken SN, Yeaman S, Holliday JA, Wang TL, Curtis-McLane S. Adaptation, migration or extirpation: climate change outcomes for tree populations. Evol Appl. 2008;1(1):95-111.

70. Beier P. A rule of thumb for widths of conservation corridors. Conserv Biol. 2019;33(4):976-8.

71. Hannah L, Flint L, Syphard AD, Moritz MA, Buckley LB, McCullough IM. Fine-grain modeling of species' response to climate change: holdouts, stepping-stones, and microrefugia. Trends Ecol Evol. 2014;29(7):390-7.

72. Colautti RI, Barrett SCH. Rapid adaptation to climate facilitates range expansion of an invasive plant. Science. 2013;342(6156): 364-6.

73. Corlett RT, Westcott DA. Will plant movements keep up with climate change? Trends Ecol Evol. 2013;28(8):482-8.

74. Zahawi RA, Augspurger CK. Tropical forest restoration: Tree islands as recruitment foci in degraded lands of Honduras. Ecol Appl. 2006;16(2):464-78.

75. Guariguata MR, Cornelius JP, Locatelli B, Forner C, SanchezAzofeifa GA. Mitigation needs adaptation: Tropical forestry and climate change. Mitig Adapt Strateg Glob Chang. 2008;13(8): 793-808.

76. Jump AS, Penuelas J. Running to stand still: adaptation and the response of plants to rapid climate change. Ecol Lett. 2005;8(9): 1010-20.

77. Planty-Tabacchi AM. Invasions of riparian corridors in southwestern France by exotic plant species. Bull Fr Peche Piscic. 1997;344/ 345:427-39.

78. Planty-Tabacchi AM, Tabacchi E, MJS B. In: Brundu G, Brock J, Camarda I, Child L, Wade M, editors. Invasions of river corridors 
by exotic plant species: Patterns and causes. Leiden: Backhuys Publishers; 2001. p. 221-33.

79. Resasco J, Haddad NM, Orrock JL, Shoemaker D, Brudvig TA, Damschen EI, et al. Landscape corridors can increase invasion by an exotic species and reduce diversity of native species. Ecology. 2014;95(8):2033-9.

80. Alexander JM, Diez JM, Levine JM. Novel competitors shape species' responses to climate change. Nature. 2015;525(7570): 515-8.

81. Isbell F, Craven D, Connolly J, Loreau M, Schmid B, Beierkuhnlein $\mathrm{C}$, et al. Biodiversity increases the resistance of ecosystem productivity to climate extremes. Nature. 2015;526(7574):574-U263.

82. Oliver TH, Heard MS, Isaac NJB, Roy DB, Procter D, Eigenbrod F, et al. Biodiversity and Resilience of Ecosystem Functions. Trends Ecol Evol. 2015;30(11):673-84.

83. Sgro CM, Lowe AJ, Hoffmann AA. Building evolutionary resilience for conserving biodiversity under climate change. Evol Appl. 2011;4(2):326-37.

84. Rice KJ, Emery NC. Managing microevolution: restoration in the face of global change. Front Ecol Environ. 2003;1(9):469-78.

85. Jones HP, Jones PC, Barbier EB, Blackburn RC, Benayas JMR, Holl KD, et al. Restoration and repair of Earth's damaged ecosystems. P Roy Soc B-Biol Sci. 2018;285(1873):8 This meta-analysis reveals that, while ecosystems are recovering following human disturbance, they rarely recover completely, and that active restoration does not result in faster or more complete recovery than passive restoration.

86. DeLang CO, Yuan Z. China's Grain for Green program: A review of the largest ecological restoration and rural development program in the world. Cham: Springer; 2015. 229 p.

87. Lieberman L, Hahn B, Landres P. Manipulating the wild: a survey of restoration and management interventions in US wilderness. Restor Ecol. 2018;26(5):900-8.

88. DeLuca TH, Aplet GH, Wilmer B, Burchfield J. The unknown trajectory of forest restoration: A call for ecosystem monitoring. J For. 2010;108(6):288-95.

89. Reif MK, Theel HJ. Remote sensing for restoration ecology: Application for restoring degraded, damaged, transformed, or destroyed ecosystems. Integr Environ Assess Manag. 2017;13(4):614-30.

90. D'Antonio CM, Yelenik SG, Mack MC. Ecosystem vs. community recovery 25 years after grass invasions and fire in a subtropical woodland. J Ecol. 2017;105(6):1462-74.

91. Ewel JJ, Putz FE. A place for alien species in ecosystem restoration. Front Ecol Environ. 2004;2(7):354-60.

92. Hobbs RJ, Higgs E, Harris JA. Novel ecosystems: implications for conservation and restoration. Trends Ecol Evol. 2009;24(11):599 605.

93. Holl KD, Aide TM. When and where to actively restore ecosystems? Forest Ecol Manag. 2011;261(10):1558-63.

94. Ostertag R, Warman L, Cordell S, Vitousek PM. Using plant functional traits to restore Hawaiian rainforest. J Appl Ecol. 2015;52(4):805-9.

95. Ellison D, Futter MN, Bishop K. On the forest cover-water yield debate: from demand- to supply-side thinking. Glob Change Biol. 2012;18(3):806-20.

96. Feng XM, Fu BJ, Lu N, Zeng Y, Wu BF. How ecological restoration alters ecosystem services: an analysis of carbon sequestration in China's Loess Plateau. Sci Rep. 2013;3:5.

97. Hua FY, Wang L, Fisher B, Zheng XL, Wang XY, Yu DW, et al. Tree plantations displacing native forests: The nature and drivers of apparent forest recovery on former croplands in Southwestern China from 2000 to 2015. Biol Conserv. 2018;222:113-24.
98. Dye PJ, Bosch JM. Sustained water yield in afforested catchments - the South African experience. Sustainable Forest Management. Dordrecht: Springer; 2000. p. 99-120.

99. van Wilgen BW, Wannenburgh A. Co-facilitating invasive species control, water conservation and poverty relief: achievements and challenges in South Africa's Working for Water programme. Curr Opin Environ Sustain. 2016;19:7-17.

100. Carrington D. Greta Thunberg: 'We are ignoring natural climate solutions'. The Guardian. 2019 Thursday, September 19, 2019; Sect. Climate Change.

101. Veldman JW, Buisson E, Durigan G, Fernandes GW, Le Stradic S, Mahy G, et al. Toward an old-growth concept for grasslands, savannas, and woodlands. Front Ecol Environ. 2015;13(3):154 62.

102. Berthrong ST, Jobbagy EG, Jackson RB. A global meta-analysis of soil exchangeable cations, $\mathrm{pH}$, carbon, and nitrogen with afforestation. Ecol Appl. 2009;19(8):2228-41.

103. Holl KD. Old field vegetation succession in the neotropics. In: Hobbs RJ, Cramer VA, editors. Old Fields. Washington, DC: Island Press; 2007. p. 93-117.

104. Clark JS. Why trees migrate so fast: Confronting theory with dispersal biology and the paleorecord. Am Nat. 1998;152(2):204-24.

105. McLachlan JS, Clark JS, Manos PS. Molecular indicators of tree migration capacity under rapid climate change. Ecology. 2005;86(8):2088-98.

106. von Holle B, Delcourt HR, Simberloff D. The importance of biological inertia in plant community resistance to invasion. J Veg Sci. 2003;14(3):425-32.

107. Loarie SR, Duffy PB, Hamilton H, Asner GP, Field CB, Ackerly DD. The velocity of climate change. Nature. 2009;462(7276): 1052-U1111.

108. von Holle B, Motzkin G. Historical land use and environmental determinants of nonnative plant distribution in coastal southern New England. Biol Conserv. 2007;136(1):33-43.

109. Chazdon RL. Second Growth: The promise of tropical forest regeneration in an age of deforestation. Chicago: University of Chicago Press; 2014.

110. Scherer-Lorenzen M. Functional diversity affects decomposition processes in experimental grasslands. Funct Ecol. 2008;22(3): $547-55$.

111. Holl KD, Cairns J. Monitoring and appraisal, vol. 1: Handbook of Ecological Restoration; 2002. p. 411-32.

112. Long E, Biber E. The Wilderness Act and climate change adaptation. Environ Law. 2014;44:658-94.

113. Chazdon RL. Beyond deforestation: Restoring forests and ecosystem services on degraded lands. Science. 2008;320(5882):145860 .

114. Rouget M, Cowling RM, Lombard AT, Knight AT, Graham IHK. Designing large-scale conservation corridors for pattern and process. Conserv Biol. 2006;20(2):549-61.

115. Cole RJ, Holl KD, Keene CL, Zahawi RA. Direct seeding of latesuccessional trees to restore tropical montane forest. For Ecol Manag. 2011;261(10):1590-7.

116. Thomas E, Jalonen R, Loo J, Boshier D, Gallo L, Cavers S, et al. Genetic considerations in ecosystem restoration using native tree species. For Ecol Manag. 2014;333:66-75.

117. Stephens SL, Millar CI, Collins BM. Operational approaches to managing forests of the future in Mediterranean regions within a context of changing climates. Environ Res Lett. 2010;5(2):9.

Publisher's Note Springer Nature remains neutral with regard to jurisdictional claims in published maps and institutional affiliations. 